\title{
Notes on some rare polypores, found in Russia 3. Genera Anomoloma, Hyphodontia, Lindtneria, and Sistotrema
}

\author{
WJACHESLAV A. SPIRIN and IVAN V. ZMITROVICH
}

SPIRIN, W. A. \& ZMITROVICH, I. 2007: Notes on some rare polypores, found in Russia 3. Genera Anomoloma, Hyphodontia, Lindtneria, and Sistotrema. - Karstenia 47: 0-0. Helsinki. ISSN 0453-3402.

\begin{abstract}
Anomoloma albolutescens (Romell) Niemelä \& K.H. Larss. is found for the first time in European Russia. Ecology and distribution of this species are briefly reviewed. Poria buxi Bondartsev is a later synonym of Hyphodontia flavipora (Cooke) Sheng H. Wu. Hyphodontia radula (Schrad. : Fr.) E. Langer \& Vesterholt was found to be widely distributed in hemiboreal European Russia. Lindtneria trachyspora (Bourdot \& Galzin) Pilát and Sistotrema dennisii Malençon are reported as new to Russia. Sistotrema brunneolum Spirin \& Zmitr. is described as a new species closely related to S. alboluteum (Bourdot \& Galzin) Bondartsev \& Singer. The new species is characterized by relatively firm, brownish, porioid basidiocarps, two- or four-sterigmate basidia, and short-cylindrical to ellipsoid, thick-walled spores. The isolated position of both $S$. brunneolum and $S$. alboluteum within the genus Sistotrema is discussed.
\end{abstract}

Key words: corticioid fungi, polypores, virgin forest.

Wjacheslav Spirin, St. Petersburg University of Humanities, Fuchika 15, 192238 St.Petersburg, Russia

Ivan Zmitrovich, Komarov Botanical Insitute RAS, Popova 2, 197376 St. Petersburg, Russia

\section{Introduction}

This paper is devoted to studies on some polypores closely related or belonging to the genera where most of the species have smooth, tuberculate or odontioid (i.e. non-poroid) hymenophore, or the so-called corticioid fungi. Most of the species treated here are extremely rare, ephemeral, and therefore data on their ecology and substrate preferences are very scanty. A new porioid Sistotrema species, $S$. brunneolum, is described.

\section{Material and methods}

The microscopic routine used in this study was described in Spirin and Zmitrovich (2003). The material is deposited in the mycological herbarium of the Botanical Museum, University of Helsinki, Finland $(\mathrm{H})$ and in Komarov Botanical Institute, St. Petersburg, Russia (LE). The plant communities of the research area were described by Spirin (2005), and the polypore names are given according to Niemelä (2005) and Niemelä et al. (2007).

\section{Species descriptions}

Anomoloma albolutescens (Romell) Niemelä \& K.H. Larss.

Syn. Anomoporia albolutescens (Romell) Pouzar

First Russian finds of this very rare polypore were reported from Altai Region (Bondartseva 1972), and for more than 30 years A. albolutescens remained known in the country only from Siberia. Our record treated below is the first one for European Russia. The species was collected in very old (over 200 years old) southern-taiga 
forest, dominated by Picea abies, Abies sibirica, and Tilia cordata. The substrate was very rotten spruce trunk with a large cavity inside; intensively developing fruitbodies were seen there.

The present record agrees well with current species concept (Niemelä 1994). Basidiospores are (3.9-) 4.1-5.2 (-5.4) × 3.1-3.5 (-3.6) $\mu \mathrm{m}$, ellipsoid, with flat ventral side, amyloid, acyanophilous.

Anomoloma albolutescens is very rare everywhere, and found in Sweden (type locality, Romell 1911), Norway, Finland, Russian Far East, Kazakhstan, China, and North America (Niemelä 1994).

Specimens examined: Russia. Nizhny Novgorod Reg.: Sharanga Dist., Kilemarsky Nat. Res., Picea abies, 17.VIII.2004 Spirin 2137 (H, LE, W.S.). Finland. Etelä-Häme: Vesijako Strict Nat. Res., P. abies, 9.VIII.1981 Kotiranta $2886(\mathrm{H})$.

Hyphodontia flavipora (Cooke) Sheng $\mathrm{H}$. Wu Syn. Schizopora flavipora (Cooke) Ryvarden

Poria buxi was described as a new species by Bondartsev (1940), and was later combined by him into the genus Aporpium Bondartsev \& Singer (Bondartsev 1953). For a long time, this name remained forgotten: both Donk (1974) and Ryvarden (1991) gave no data on a contemporary position of this taxon. Bondartseva (1998) was of opinion that Poria buxi is identical to Oligoporus sericeomollis (Romell) Bondartseva.

Type specimen (LE 25311) consists of two pieces of porioid fungus with corky, buff-coloured tubes; pores are angular, ca. 4-6 per mm. Microscopically, this specimen is characterized by clamped narrow hyphae bearing swollen apices at the dissepiment edges; basidiospores are ellipsoid, (4.0-) 4.1-5.2 (-5.3) × (2.6-) 2.7-3.4 $(-3.6) \mu \mathrm{m}$, inamyloid. Our conclusion is that it belongs to Hyphodontia flavipora (Cooke) Sheng $\mathrm{H}$. Wu, which is widely distributed in southern Europe.

Selected specimens: Russia. Krasnodar Reg.: Hosta, Buxus sempervirens, 20.IX.1938 Vasilyeva (LE 25311, holotype of Poria buxi). Nizhny Novgorod Reg.: Arzamas Dist., Pustynsky Nat Res., Quercus robur, 2.VII.2000 Spirin (LE 213649); Lukoyanov Dist., Razino, Betula pubescens and Q. robur, 9 - 11.VII.2005 Spirin 2362, 2385 (H), Sanki, Quercus robur, 18.VIII.2006 Spirin $2613(\mathrm{H})$; Sharanga Dist., Kilemarsky
Nat. Res., Tilia cordata, 22.VIII.2004 Spirin $2273(\mathrm{H})$.

Hyphodontia radula (Schrad. : Fr.) E. Langer \& Vesterholt

Syn. Schizopora radula (Schrad. : Fr.) Hallenberg

This species was not known in Russia for a long time (Bondartseva 1998). First records were published by Niemelä et al. (2001) and Spirin (2002). Hyphodontia radula has a remarkably wide distribution in hemiboreal zone in Russia, preferring broad-leaved forests; its main substrate is Quercus robur.

Modern descriptions of this species were published by Niemelä (1987) and Vampola (1990). These authors questioned the miticity of the basidiocarps as a distinguishing character between $H$. radula ('monomitic') and $H$. paradoxa ('dimitic'), which agrees well with our results. Evidently, the dominance of thick-walled skeletal-like hyphae depends strongly on environmental conditions. The specimens collected in exposed habitats have clearly 'dimitic' construction, with dominating sclerified hyphae without clamps. The best differentiating character of $H$. radula is the spore length, not exceeding 5.5 $\mu \mathrm{m}$ (the measurements must be made in Cotton Blue).

Selected specimens: Hyphodontia radula. Russia. Nizhny Novgorod Reg., Lukoyanov Dist., Sanki, Quercus robur, 7.VIII.2005 Spirin 2310 (H); Kurley, Q. robur, 13.VIII.2005 Spirin $2421(\mathrm{H})$; Nizhny Novgorod City, Q. robur, 29.X.2000 (LE 213128). - Hyphodontia paradoxa. Russia. Nizhny Novgorod Reg., Lukoyanov Dist., Kurley, Q. robur, 13.VIII.2005 Spirin $2425(\mathrm{H})$.

\section{Lindtneria trachyspora (Bourdot \& Galzin) Pilát}

This rare fungus is known from North America and some European countries (Gilbertson \& Ryvarden 1986, Ryvarden \& Gilbertson 1993); here it is published as new to Russia. It is easily identified in the microscope due to coarsely ornamented brownish spores 6.8-8.2 $(-8.5) \times$ 6.4-7.6 (-8.0) $\mu \mathrm{m}$, strongly cyanophilous in juvenile state. Basidia of L. trachyspora are very large, suburniform or bladder-shaped, and comprise numerous strongly cyanophilous granules. This feature links Lindtneria with members of 
the corticioid genus Cristinia Parmasto (Jülich 1982).

Specimen examined: Russia. Primorye Reg.: Khasansky Dist., Kedrovaya Pad' Nat. Res., Pinus koraiensis, 21.VIII.2005 Psurtseva (LE 214902).

Sistotrema alboluteum (Bourdot \& Galzin) Bondartsev \& Singer

This rare saprotrophic fungus was found in Russia quite recently (Kotiranta \& Mukhin 1998). To the first locality from Kamchatka (Russian Far East), we add here another record from Nizhny Novgorod Region (European Russia).

S. alboluteum produces bright-yellow, small, porioid basidiocarps on strongly decomposed wood of both conifers and angiosperms, or even on debris. In the microscope it is easily identified due to the 2-4-sterigmate urniform basidia and large, thick-walled, subglobose spores, 4.6-6.3 $\mu \mathrm{m}$ in diam. See notes to $S$. brunneolum.

Specimens examined: Russia. Nizhny Novgorod Reg.: Bor Dist., Kerzhensky Nat. Res., very rotten Betula, 24.IX.1998 Spirin (LE 212644, H).

Sistotrema brunneolum Spirin \& Zmitr., spec. nova. - Fig. 1.

Carpophorum resupinatum, porioideum, fragile, colore pallido-ochraceum vel brunnescens. Systema hypharum monomiticum; hyphae fibulatae. Basidia urniformia, cum $2-4$ sterigmatibus. Sporae crassitunicatae, brevicylindriceae vel ellipsoideae, $4.6-6.7 \times 2.5-2.9 \mu \mathrm{m}$.

Holotype: Russia. Nizhny Novgorod Reg.: Sharanga Dist., Kilemarsky Nat. Res., Populus tremula, 17.VIII.2004 Spirin 2127 (LE 215000, isotype in $\mathrm{H}$ ).

Etymology: brunneolum (Lat., adj.) - with brown hues in its colour.

Basidiocarps short-living annual, resupinate, widely effused (up to $15 \mathrm{~cm}$ in longest dimension), soft-waxy and fragile in fresh condition, soft-corky and relatively hard when dry. Margin distinct, firm (of cardboard-like consistence), cream to pale-ochraceous or even brownish, 2-4 $\mathrm{mm}$ wide; rhizomorphs absent. Pore surface at first cream to pale ochraceous, later resinous brown (especially marginal areas), even; pores angular, sometimes merging together, lacerate and strongly elongated on sloping substrate, (3-) 4-6 per $\mathrm{mm}$, with thin, entire or minutely denticulate orifices. Section: subiculum distinct, white or pale-cream, soft-corky, 1-2 mm thick; tubes concolorous with pore surface, soft-waxy when fresh, hardening in dry state, $1-5 \mathrm{~mm}$ thick. Odour faint, fungoid; taste mild.

Hyphal structure monomitic; all hyphae thinwalled, with abundant clamps, moderately cyanophilous.

Subiculum: Hyphae hyaline, richly branched and abundantly septate with clamp connections, irregularly arranged, 3.5-7 $\mu \mathrm{m}$ wide, some hyphal cells with numerous oily droplets.

Tubes. Hyphae hyaline, branched at sharp angles, with abundant septa and large clamps, sometimes with greasy drops, $2.5-4 \mu \mathrm{m}$ wide; trama irregular to subparallel. No cystidia. Basidia urniform, large, 15-22 × 4.5-6 (-7) $\mu \mathrm{m}$, with 2 or 4 sterigmata (up to $6 \mu \mathrm{m}$ long), content homogeneous. Basidioles of the same size as basidia, bladder-shaped.

Jülich, W. 1982: Higher taxa of Basidiomycetes. - Bibl. Mycol. 85: 1-485.

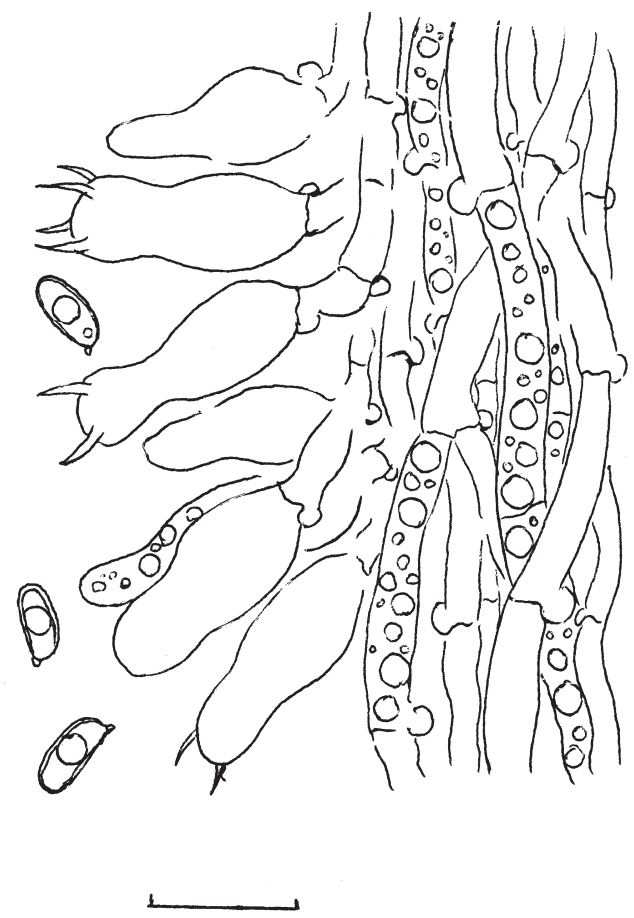

Fig. 1. Sistotrema brunneolum: hymenium and spores. Scale bar $=10 \mu \mathrm{m}$. 
Kotiranta, H. \& Mukhin, V.A. 1998: Polyporaceae and Corticiaceae of an isolated forest of Abies nephrolepis in Kamchatka, Russian Far East. - Karstenia 38: 69-80.

Spores: Basidiospores short-cylindrical to narrowly ellipsoid, with flat or slightly rounded ventral side, (4.3-) 4.6-6.7 (-7.3) × (2.3-) 2.5-2.9 $(-3.4) \mu \mathrm{m}$, thick-walled, inamyloid, moderately cyanophilous.

Distribution and ecology: - Nowadays S. brunneolum is known from the type locality only. The site represents old undisturbed southern taiga forest where Anomoloma albolutescens was collected, too (see above). The species was found on still standing dead trunk of Populus tremula. Evidently, this species is ephemeral and appears only in rainy seasons. Visually, the rot produced by $S$. brunneolum is white; however, this fact must be confirmed with cultural studies.

Identification and taxonomy: - Undoubtedly, our new species is very close to $S$. alboluteum. The reasons to describe a new species are the peculiar macromorphology and disagreeing spore dimensions. Superficially, S. brunneolum is strongly reminiscent of Ceriporiopsis species, especially C. resinascens (Romell) Domański. Common features are ochraceous-brownish colours of pore surface contrasting with paler margin, and the number of pores per mm. Unlike Sistotrema alboluteum, our new species is relatively firm, and has no rhizomorphs. However, in the microscope these two species are very similar, but differ clearly by spore dimensions: globose to subglobose in $S$. alboluteum $(\mathrm{Q}=1.0-1.13)$ versus short-cylindrical to ellipsoid in S. brunneolum $(\mathrm{Q}=1.87-2.1)$. Two other porioid Sistotrema species known in Europe, $S$. muscicola (Pers.) S. Lundell and S. dennisii Malençon, differ in having $6-8$-sterigmate basidia and much smaller spores.

Sistotrema alboluteum and S. brunneoum share an isolated position within the genus due to constantly porioid basidiocarps, cyanophilous hyphae, large basidia with two or four sterigmata, and thick-walled cyanophilous spores. A few Sistotema species have cyanophilous hyphae and spores; this character links them with the genus Botryobasidium Donk (Jülich \& Stalpers 1980, Kotiranta \& Saarenoksa 1990). Probably, the current generic concept of Sistotrema is very wide, and splitting into more homogeneous unities might be welcome. Unfortunately, a very small number of the Sistotrema species are included in molecular studies (Larsson et al. 2004, Binder et al. 2005), and therefore we cannot make any clear conclusions.

\section{Sistotrema dennisii Malençon}

New to Russia. This very rare species is found in some European countries and North Africa (Ryvarden \& Gilbertson 1994, Niemelä et al. 2001). Our specimen was collected on fallen, decorticated Picea abies, and is characterized by $4-6-8-$ spored, urniform basidia, and short-cylindrical, slightly curved spores, $3.1-4.3 \times 2.1-2.6 \mu \mathrm{m}$. Hyphae are clamped and almost acyanophilous.

Specimens examined: Russia. Nizhny Novgorod Reg.: Sharanga Dist., Kilemarsky Nat. Res., Picea abies, 17.VIII.2004 Spirin 2123 (LE, H). Finland. Etelä-Häme: Janakkala, P. abies, 8.IX.2000 Salonen $6(\mathrm{H})$.

Acknowledgments: We are very grateful to Prof. Tuomo Niemelä (Helsinki) for reviewing of the manuscript and valuable remarks on it. Prof. Teuvo Ahti (Helsinki) kindly revised the Latin. Also we would like to thank Dr. Nadezhda Psurtseva (Komarov Botanical Institute, St. Petersburg, Russia), who furnished us with a specimen of Lindtneria trachyspora.

\section{References}

Binder, M., Hibbett, D.S., Larsson, K.H., Larsson, E., Langer, E. \& Langer, G. 2005: The phylogenetic distribution of resupinate forms across the major clades of mushroom-forming fungi. - Systematics and Biodiversity 3: 113-157.

Bondartsev, A.S. 1940: O novyh gribah sem. Polyporaceae. - Bot. Mat. Otd. Spor. Rast. 5 (1 - 3): 17-23 (in Russian).

Bondartsev, A.S. 1953: Trutovye griby evropeyskoy chasti SSSR i Kavkaza. - Izdatel'stvo Akad. Nauk SSSR, Moskva, Leningrad. 1106 pp. (in Russian).

Bondartseva, M.A. 1972: K sistematike roda Fibuloporia Bond. \& Singer. - Nov. Syst. Plant. Non Vasc. 9: 132 -136 (in Russian).

Bondartseva, M.A. 1998: Opredelitel' gribov Rossii. Por. Afilloforovye 2. - Nauka, St.-Petersburg. 391 pp. (in Russian).

Donk, M.A. 1974: Check list of European polypores. - Verh. der Konink. Neder. Akad. van Wetenshappen, Tweede Reeks, 62: 1-472.

Gilbertson, R.L. \& Ryvarden, L. 1986: North American Polypores 1: Abortiporus - Lindtneria. -Pp. 1-433. Fungiflora, Oslo.

Jülich, W. 1982: Higher taxa of Basidiomycetes. - Bibl. Mycol. 85: 1-485.

Jülich, W. \& Stalpers, J.A. 1980: The resupinate nonporoid Aphyllophorales of the Temperate Northern 
Hemisphere. - Verh. der Konink. Neder. Akad. van Wetenshappen, Tweede Reeks, 74: 1-335.

Kotiranta, H. \& Mukhin, V.A. 1998: Polyporaceae and Corticiaceae of an isolated forest of Abies nephrolepis in Kamchatka, Russian Far East. - Karstenia 38: 69-80.

Kotiranta, H. \& Saarenoksa, R. 1990: Reports on Finnish corticolous Aphyllophorales (Basidiomycetes). - Karstenia 30: 43-69.

Larsson, K.H., Larsson, E. \& Kõljalg, U. 2004: High phylogenetic diversity among corticioid homobasidiomycetes. - Mycol. Research 108: 983-1002.

Niemelä, T. 1987: The raduloid species of Schizopora - Beiträge zur Kenntnis der Pilze Mitteleuropas 3: 365-370.

Niemelä, T. 1994: Five species of Anomoporia - rare polypores of old forests. - Ann. Bot. Fennici 31: 93-115.

Niemelä, T. 2005: Käävät, puiden sienet. Polypores, lignicolous fungi. - Norrlinia 13: 1 - 320 (in Finnish).

Niemelä, T., Kinnunen, J., Lindgren, M., Manninen, O., Miettinen, O., Penttilä, R. \& Turunen, O. 2001: Novelties and records of poroid Basidiomycetes in Finland and adjacent Russia. - Karstenia 41: 1-21.
Niemelä, T., Larsson, K.H., Dai, Y.C. \& Larsson, E. 2007: Anomoloma, a new genus separated from Anomoporia on the basis of decay type and nuclear rDNA sequence data. - Mycotaxon 100: 305-317.

Romell, L. 1911: Hymenomycetes of Lappland. - Ark. Bot. 11 (3): 1-31.

Ryvarden, L. 1991: Genera of polypores. Nomenclature and taxonomy. - Synopsis Fungorum 5: 1-363.

Ryvarden, L. \& Gilbertson, R.L. 1993-1994: European Polypores. - Synopsis Fungorum 6-7: 1-743.

Spirin, W. 2002: Aphyllophoroid macromycetes in oak forests of Nizhny Novgorod Region. - Mikol. Fitopat. 36 (2): 43-52 (in Russian).

Spirin, W. 2005: Notes on some rare polypores, found in Russia 2. Junghuhnia vitellina sp. nova, plus genera Cinereomyces and Skeletocutis. - Karstenia 45: 103 $-113$.

Spirin, W. \& Zmitrovich, I. 2003: Notes on some rare polypores, found in Russia 1. Genera Antrodiella, Gelatoporia, Irpex, Oxyporus, Pilatoporus, and Porpomyces. - Karstenia 43: 67-82.

Vampola, P. 1990: Notes on the distinguishing of Schizopora paradoxa and Schizopora radula. - Mykol. Listy 39: 1-3 (in Czech). 